\title{
Органна дисфункція в динаміці гострого панкреатиту
}

\author{
О. Ю. Черкун, Д. А. Ситнік, А. С. Калюжка, В. Д. Шейко \\ Українська медична стоматологічна академія, м. Полтава
}

\section{The organ's dysfunction in dynamic of an acute pancreatitis}

\author{
O. Yu. Cherkun, D. A. Sytnik, A. S. Kaliuzhka, V. D. Sheiko
}

Ukrainian Medical Stomatological Academy, Poltava

\begin{abstract}
Peферат
Мета. Визначити динаміку органної дисфункції у залежності від характеру локальних ускладнень гострого панкреатиту (ГП).

Матеріали і методи. Проаналізовано результати лікування 422 хворих із ГП, які перебували в хірургічному відділенні Полтавської обласної клінічної лікарні 32010 по 2015 р. Середньотяжкий і тяжкий панкреатит із розвитком локальних парапанкреатичних ускладнень діагностовано у 107 (25,4\%) хворих.

Результати. При середньотяжкому перебігу ГП транзиторну первинну органну дисфункцію спостерігали у 65,9\% хворих. Друга хвиля поліорганної недостатності (ПОН) виникла у 18,1\% хворих внаслідок прогресування гнійно-септичних ускладнень (ГСУ) на 10 - 14-ту добу захворювання. При тяжкому ГП ПОН у 7,9\% пацієнтів мала безперервний, у $14,3 \%$ - інтермітуючий характер, обумовлений розвитком ГСУ.

Висновки. Ризик другої хвилі ПОН та несприятливого перебігу захворювання зростає з поширеністю локальних парапанкреатичних ускладнень на три і більше анатомічних ділянок переважно у пацієнтів з тяжким ГП.

Ключові слова: гострий панкреатит; гнійно-септичні ускладнення; органна дисфункція.

Abstract

Objective. To determine a dynamics of the organ's dysfunction, depending on character of local complications of an acute pancreatitis (AP)

Materials and methods. Results of treatment in 422 patients, suffering an AP, who were treated in Surgical Department of Poltava Regional Clinical Hospital in 2010 - 2015 yrs. Moderate and severe pancreatitis with development of local parapancreatic complications were diagnosed in 107 (25.4\%) patients.

Results. In moderate course of AP a transitory primary ohgan's dysfunction was observed in $65.9 \%$ patients. Second wave of the polyorgan insufficiency have occurred in $18.1 \%$ patients due to progress of purulent-septic complications on the $10-14-$ th day of the disease. In severe AP the polyorgan insufficiency in $7.9 \%$ patients have had continuous and in $14.3 \%-$ intermittent character, caused by development of purulent-septic complications.

Conclusion. The risk of a second wave of the polyorgan insufficiency and unfavorable course of the disease rises together with extent of local parapancreatic complications on three and more anatomic sites, predominantly in patients with severe AP. Keywords: acute pancreatitis; purulent-septic complications; the organ's dysfunction.
\end{abstract}

У невідкладній хірургії ГП відводять третє місце серед гострих хірургічних захворювань. Зростання захворюваності на ГП у осіб працездатного віку, тривала їх госпіталізація з великими фінансовими витратами на лікування та значною часткою незадовільних результатів, включаючи високу летальність, зумовлюють неабияку соціально-медичну проблему. Захворюваність на ГП у світі становить від 8,6 до 47 спостережень на 10000 населення. Тяжкість стану хворих і летальність значною мірою залежать від розвитку ГСУ та ПОН. Летальність при ГСУ за даними різних авторів коливається від 30 до 65\% [1, 2].

Сучасні принципи та підходи до лікування ГП з ГСУ дали змогу дещо зменшити летальність, проте вона залишається значною. Незважаючи на те що більше третини хворих із ГП помирає через розвиток ГСУ, лікувальна тактика цієї категорії пацієнтів залишається чітко не визначеною [3, 4].

Мета дослідження: визначити динаміку органної дисфункції у залежності від характеру локальних ускладнень ГП.

\section{Матеріали і методи дослідження}

Проаналізовано результати лікування 422 хворих із ГП у хірургічному відділенні Полтавської обласної клінічної лікарні з 2010 по 2015 р. Усі пацієнти госпіталізовані до стаціонару на 1 - 7-му добу від початку захворювання. Із них у 315 (74,6\%) діагностовано легкий ГП. Ці пацієнти отримували консервативну терапію і на 7 - 10-ту добу були виписані зі стаціонару. Середньотяжкий і тяжкий ГП із розвитком локальних парапанкреатичних ускладнень діагностовано у 107 (25,4\%) хворих. Чоловіків було 67 (62,6\%), жінок - 40 (37,4\%). Вік хворих - від 22 до 81 року, середній - $(47,9 \pm 1,5)$ року. Тяжкість стану пацієнтів визначали за шкалою BISAP (The Bedside Index For Severity in Acute Pancreatitis), наявність ПОН констатували за шкалою Marshall (модифікація 2012 р.) [5]. Пацієнти обстежені згідно з наказом МОЗ України № 297 від 2 квітня 2010 року.

Всім пацієнтам для діагностики локальних та гнійносептичних ускладнень застосовували ультразвукове дослідження (УЗД), комп'ютерну томографію (КТ) та тонко- 
голкову пункцію рідинних скупчень. Для зручності аналізу поширеності локальних парапанкреатичних ускладнень заочеревинний простір умовно розділили на вісім ділянок: перша - парапанкреатична клітковина, сальникова сумка; друга - ділянка селезінкового кута ободової кишки; третя - клітковина панкреатодуоденальної зони; четверта - ліва піддіафрагмальна ділянка; п'ята - права ретроколярна ділянка; шоста - ліва ретроколярна ділянка; сьома - корінь брижі тонкої кишки та міжпетельні скупчення; восьма - клітковина малого таза.

Пацієнтів розподілили на дві групи в залежності від ступеня тяжкості ГП згідно з Міжнародною класифікацією гострого панкреатиту робочої групи Атланта - 2012 [6]. До 1-ї групи увійшли 44 пацієнти з ГП середньої тяжкості. Чоловіків було 27 (61,3\%), жінок - 17 (38,7\%). Середній вік пацієнтів становив $(44,8 \pm 1,7)$ року. Другу групу склали 63 пацієнти з тяжким ГП. Чоловіків було 40 (63,5\%), жінок - 23 (36,5\%). Середній вік пацієнтів становив (48,1 \pm $1,6)$ року. Таким чином, групи порівнянні за віком та гендерним складом.

\section{Результати}

У всіх 44 пацієнтів 1-ї групи під час госпіталізації тяжкість стану за шкалою BISAP оцінена в 2 - 4 бали, в середньому $(2,7 \pm 0,32)$ бала, кількість балів за шкалою Marshall більше 2 в одній чи двох системах із трьох спостерігали у 29 (65,9\%) пацієнтів. На фоні консервативної терапії через 24 - 48 год ПОН регресувала у всіх цих пацієнтів. Через 4 - 7 діб від початку захворювання під час КТ із внутрішньовенним контрастуванням спостерігали набряк підшлункової залози та інфільтрацію парапанкреатичної клітковини, яка поширювалася на одну анатомічну ділянку у 65,9\% пацієнтів, дві - у 18,2\%, три і більше - у 15,9\%.

На 7-му добу лікування тяжкість стану пацієнтів за шкалою BISAP оцінена в $(2,4 \pm 0,3)$ бала. Органної і поліорганної дисфункції не спостерігали у жодного пацієнта (2 бали за шкалою Marshall у жодній із систем не виявлено). Під час УЗД і КТ інфільтрація парапанкреатичної клітковини у 26 (59,1\%) пацієнтів регресувала, з них у 8 (21,6\%) розміри інфільтрату зменшилися, постнекротичні рідинні скупчення спостерігали у 18 (40,9\%). Ознак інфікування рідинних скупчень не було. Хірургічних втручань на даному етапі пацієнти не потребували. Поширеність локального процесу на одну анатомічну ділянку виявлено у 61,3\% хворих, дві - у 22,8\%, три і більше - у 15,9\%.

На 10 - 14-ту добу лікування тяжкість стану пацієнтів за шкалою BISAP була оцінена у $(2,5 \pm 0,31)$ бала, ознаки ПОН констатували у 8 (18,1\%) хворих, що свідчило про розвиток іiі другої хвилі. Під час УЗД та КТ інфільтрацію парапанкреатичної клітковини без рідинного компонента, що поширювалася на одну-дві анатомічні ділянки, діагностовано у 7 (15,9\%) хворих. Хірургічних втручань пацієнти не потребували. Парапанкреатичні рідинні скупчення виявлено у 37 пацієнтів: в одній анатомічній ділянці - у 22 (59,4\%), двох - у 8 (21,6\%), трьох і більше - у 7 (18,9\%). Після виконання діагностичної пункції стерильні парапанкреатичні скупчення діагностовано у 28 (75,6\%) пацієнтів. ГСУ розвинулись у 9 (24,4\%) пацієнтів, наявність секвестрів виявлено у 7 (18,9\%) 3 них.
Тривалість лікування пацієнтів даної групи становила в середньому $(22,6 \pm 2,7)$ ліжко-дня. Ніхто із хворих не помер.

У всіх 63 пацієнтів 2-ї групи під час госпіталізації тяжкість стану за шкалою BISAP оцінена в 2 - 5 балів, у середньому $(2,9 \pm 0,32)$ бала. Ознаки ПОН (кількість балів за шкалою Marshall більше 2 в одній чи двох системах із трьох), що не регресувала протягом 48 год, спостерігали у 46 (73,0\%) пацієнтів.

Під час УЗД та КТ констатували, що інфільтрація парапанкреатичної клітковини поширювалася на одну анатомічну ділянку у 19 (30,2\%) хворих, дві - у 14 (22,2\%), три і більше - у 30 (47,6\%).

На 7-му добу лікування ознаки ПОН (кількість балів більше 2 в одній чи двох системах із трьох за шкалою Marshall) зберігалися у 14 (22,2\%) хворих. Тяжкість стану за шкалою BISAP оцінена в $(2,3 \pm 0,31)$ бала. Під час УЗД та КТ визначали інфільтрацію парапанкреатичної клітковини у 23 (36,6\%) пацієнтів: в одній анатомічній ділянці - у 7 (11,1\%), двох - у 4 (6,3\%), трьох і більше - у 12 (19,0\%). Парапанкреатичні рідинні скупчення виявлені у 40 (63,4\%) хворих, постнекротичні - у 13 (21,7\%). Парапанкреатичні рідинні скупчення поширювались на одну анатомічну ділянку у 12 (19,0\%) пацієнтів, дві - у 10 (15,9\%), три і більше - у 18 (28,6\%). За допомогою діагностичної та декомпресійної пункції під контролем УЗД встановлено наявність інфікування скупчень у 9 (14,3\%) пацієнтів. Чіткого відмежування парапанкреатичних рідинних скупчень не визначали, тому на даному етапі виконували пункцію під контролем УЗД.

Тяжкість стану пацієнтів за шкалою BISAP на 10 - 14-ту добу оцінена в $(2,7 \pm 0,33)$ бала. Ознаки другої хвилі ПОН спостерігали у 9 (14,3\%) хворих, персистуючу органну недостатність - у 5 (7,9\%). Під час УЗД та КТ констатували, що інфільтрат регресував у 2 (3,2\%) пацієнтів. Хірургічних втручань пацієнти не потребували. Парапанкреатичні рідинні скупчення діагностовано у 61 (96,8\%) хворого, постнекротичні - у 48 (83,2\%). Парапанкреатичні рідинні скупчення локалізувались в одній анатомічній ділянці у 15 (24,6\%) пацієнтів, двох - у 14 (22,9\%), трьох і більше - у 32 (52,5\%). Стерильними парапанкреатичні рідинні скупчення були у 8 (13,1\%) хворих. ГСУ розвинулись у 53 (86,9\%) пацієнтів. Наявність секвестрів виявлено у 30 (47,6\%) 3 них.

Тривалість лікування у 2-й групі становила в середньому $(41,2 \pm 3,9)$ ліжко-дня. Померли 20 (31,7\%) хворих.

\section{Обговорення}

При середньотяжкому ГП 65,9\% хворих мали первинну органну дисфункцію, яка виникала на фоні ферментативного некрозу підшлункової залози та парапанкреатичної клітковини однієї-двох анатомічних ділянок. Функції внутрішніх органів нормалізувались під впливом інтенсивної терапії хворих. У 18,1\% пацієнтів на другому тижні захворювання виникла друга хвиля ПОН, обумовлена розвитком та прогресуванням ГСУ. При тяжкому ГП ПОН мала безперервний або інтермітуючий характер, що було обумовлено збільшенням зони некрозу підшлункової залози та парапанкреатичної клітковини. 


\section{Висновки}

1. Тяжкість стану хворих із ГП і летальність значною мірою залежать від розвитку ГСУ та ПОН.

2. Ризик другої хвилі ПОН та несприятливий перебіг захворювання зростає з поширеністю локальних парапанкреатичних ускладнень на три і більше анатомічних ділянки переважно у пацієнтів з тяжким ГП.

\section{References}

1. Khomiak IV, Rotar VI, Rotar OV, Nazarchuk MF, Petrovskyi HH, Chermak II. Rol biolohichnykh markeriv u diahnostytsi hniino-septychnykh uskladnen hostroho nekrotychnoho pankreatytu. Klinichna khirurhiia. 2016;10:31-3. [In Ukrainian].

2. Lihonenko OV, Dihtiar II. Obmin kaltsiiu i stan perekysnoho okysnennia lipidiv pry hostromu pankreatyti. Klinichna khirurhiia. 2009;78:86-8. [In Ukrainian].

3. Kumar A, Roberts D, Wood KE, Light B, Parrillo JE, Sharma S, et al. Duration of hypotension before initiation of effective antimicrobial therapy is the critical determinant of survival in human septic shock. Crit Care Med. 2006 Jun;34(6):1589-96. doi: 10.1097/01. CCM.0000217961.75225.E9.

4. Tenner S, Baillie J, Swaroop Vege S. American College of Gastroenterology Guideline. Management of acute pancreatitis. Am J Gastroenterol. 2013;108:1400-15.

5. Banks PA, Bollen TL, Dervenis C, Gooszen HG, Johnson CD, Sarr MG, et al. Classification of acute pancreatitis - 2012: revision of the Atlanta classification and definitions by international consensus. Gut. 2013 Jan;62(1):102-11. doi: 10.1136/gutjnl-2012-302779. Epub 2012 Oct 25.

6. Working Group IAP/APA Acute Pancreatitis Guidelines. IAP/APA evidence-based guidelines for the management of acute pancreatitis. Pancreatology. 2013 Jul-Aug;13(4 Suppl 2):e1-15. doi: 10.1016/j. pan.2013.07.063. 